\title{
Epiphyton Algae on Aquatic Macrophyte (Water Hyacinth) in a Tropical Lagoon and Their Possible Use as Indicator
}

\author{
K. S. Effiong ${ }^{1, *}$, A. I. Inyang ${ }^{2}$ \\ ${ }^{1}$ Department of Marine Sciences, Faculty of Natural and Applied Sciences, University of Lagos, Akoka, Lagos, Nigeria \\ ${ }^{2}$ Department of Marine Biology, Faculty of Natural and Applied Sciences, Akwa Ibom State University, Ikot Apaden, Nigeria
}

\section{Email address:}

aniefiokinyang@yahoo.com (A. I. Inyang), kokoetteeffiong@yahoo.com (K. S. Effiong)

\section{To cite this article:}

K. S. Effiong, A. I. Inyang. Epiphyton Algae on Aquatic Macrophyte (Water Hyacinth) in a Tropical Lagoon and Their Possible Use as Indicator. International Journal of Environmental Monitoring and Analysis. Vol. 3, No. 6, 2015, pp. 404-410.

doi: 10.11648/j.ijema.20150306.14

\begin{abstract}
The epiphyton on aquatic macrophyte "Water hyacinth" and their possible use as indicator of environmental change in Yewa Lagoon, Nigeria were undertaken for six months (December, 2012- May, 2013), to know the health status of the environment and also identify pollution tolerant individual in the area. A total of 4710 individuals of 39 species belonging to 4 divisions were identified. A total of 4070 individuals (86.42\%) represents Bacillariophyta division while 205 (4.35\%), 255 (5.41\%) and $180(3.82 \%)$ individuals represent Chlorophyta, Cyanophyta and Euglenophyta respectively. Dissolved oxygen values range from $7.6 \mathrm{mg} / \mathrm{L}$ to $2.8 \mathrm{mg} / \mathrm{L}$ throughout the study period. Biochemical Oxygen Demand (BOD) varied between $7.0 \mathrm{mg} / \mathrm{L}$ and $16.0 \mathrm{mg} / \mathrm{L}$. Transparency was highest $(\leq 48.5 \mathrm{~cm})$ in dry months and lowest $(\leq 28.0 \mathrm{~cm})$. Epiphyton biomass were higher in the dry months. The pennate diatoms dominated the whole algal community. The following ideal species were recorded and could be used as biomonitoring of organic contamination in the lagoon, these include; Gomphonema parvulum, Synedra acus, Surirella ovata and Pinnularia major, Pondorina morum, Trachelomonas hispida, Phacus longicuda and Euglena sp.
\end{abstract}

Keywords: Biomonitoring, Epiphyton, Tropical Lagoon, Nutrients, Water Hyacinth

\section{Introduction}

The lagoons of the tropical south-west Nigeria open into the Atlantic Ocean through the Lagos harbour all through the year. The Yewa Lagoon with a surface area of about $17 \mathrm{~km}^{2}$ from the Nigeria-Benin Republic opens into Badagry Lagoon, [1]. Previous studies on algae in the lagoon have been confined mainly to phytoplankton [2, 4]. However, Nwankwo and Akinsoji [5], reported on the algal benthic community at the saw dust deposition site at Oko Baba along the Lagos Lagoon. With regards to epiphytic algae, there are only three works of reference. For instance, Nwankwo [6], highlighted the importance of attached algae on fish fences in the food chain of the Lagos lagoon fauna. Nwankwo and Akinsoji [7], reported on the algal epiphyton on the water hyacinth, Eichhornia crassipes (Mart.) Solms from different ecological zones in the coastal waters of south-western Nigeria. Furthermore, Nwankwo and Onitiri [8], investigated the epiphyton community on two submerged aquatic macrophytes (Utricularia $s p$ and Ceratophylum $s p$ ) in Epe lagoon, a non- tidal essentially freshwater lagoon just as the Yewa Lagoon.

Epiphyton is a complex matrix of algae and heterotrophic microbes attached to submerged substrata in almost all aquatic ecosystems [9]. It is generally known that algae provide food directly or indirectly to aquatic fauna $[10,11$, 12]. According to Welch and Isaac [13], because benthic algae assemblages are attached to substrate, their characteristics are affected by physical, chemical and biological disturbances that occur in the stream reach during the time in which the assemblages develop. Epiphyton algal communities are important components of aquatic ecosystem. Their contribution to primary production varies from $0.2 \%$ to $41 \%$ in Lakes [14]. Furthermore, the epiphyton algae with macrophyte are employed as the buffering zone of lake and lagoons [15]. They are important components of food web $[16,7]$.

Epiphyton algae are good indicators of water quality and environmental changes due to their sensitivity to external sources of fertilization [17]. Similarly, Dakashini and Soni [18], used the distribution of diatoms to reflect the average 
ecological conditions of water bodies. Munawar [19], used euglenoids as biological indicators of pollution whereas in his rating, Palmer [20], lists the genus euglena to top his 60 most tolerant genera to pollution. Other algal genera associated with organically polluted enriched waters include Scenedesmus [21], Chlorella and Chlamydomonas [22],
Cladophora [23], Euglena, Nitzschia, Phacus, Closterium [20, 24, 19, 25].

This study was carried out in order to evaluate the species composition of epiphyton and how it response to the environmental changes. Also to identify any indicator species of environmental importance in the epiphytic community.

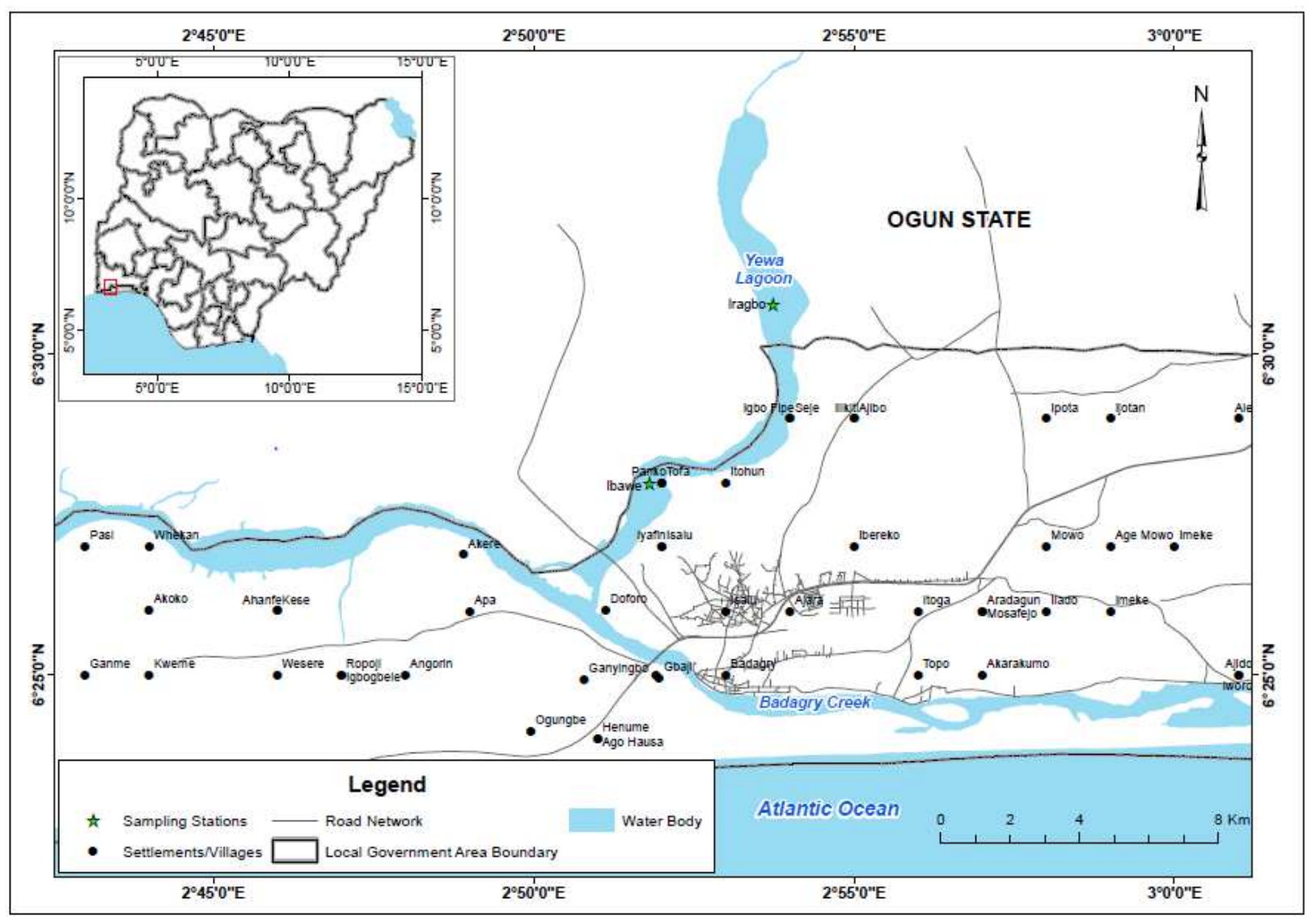

Fig. 1. Map of Yewa Lagoon showing sampling site.

\section{Materials and Methods}

\subsection{Study Area}

Yewa lagoon located in Figure 1is one of the series of coastal lagoons found along the West African coast. It is located between Nigeria-Benin Republic boarder and Badagry lagoon. The study area of this work is the Iragbo part of Yewa lagoon with coordinates (Lat. NO6 30 '46.5 and long. E002 $\left.{ }^{0} 53^{\prime} 42.5\right)$. As the other part of tropics, this area is bless by two seasons, the dry (November-March) and wet (AprilOctober). River Yewa is the major river emptying into the lagoon and has Eere and Iragbo as tributaries. Yewa is characterized by a plethora of Island for manatee traps and it also serves as a feeding site for various species of migratory birds. The site selected for this study is an area of high machrophyte abundance with Eichhornia crassipes and Lemna $s p$ as the dominant machrophyte species all through the year.

\subsection{Collection of Samples}

Water samples were collected on each trip between 09:00hrs and 14:00hrs and stored in a $250 \mathrm{ml}$ well labeled screwed caped plastic bottles and transported to the laboratory in an ice chest. Surface water temperatures were measured in-situ using mercury-in-glass thermometer and recorded to the nearest $0.1^{\circ} \mathrm{C}$. Transparency was determined using $20 \mathrm{~cm}$ white painted secchi disc while $\mathrm{pH}$ values measured using a Graffin digital $\mathrm{pH}$ meter. Dissolved oxygen concentration was determined by unmodified wrinkler method [26], conductivity and chemical oxygen demand values were determined using method described in APHA [27]. Nitrate-nitrogen, reactive phosphorus, sulphate and silicate were measured as described by APHA [27].

\subsection{Determination of Epiphyton Biomass}

Healthy plants were carefully selected to ensure uniformity in size before putting each into plastic containers with $500 \mathrm{ml}$ of tap water. The attached algae were removed mechanically by shaking vigorously in water as suggested by Forester and Schlichting [28] and preserved in a well labeled plastic container, $4 \%$ unbuffered formalin was added to fix the epiphyton sample. Another $500 \mathrm{ml}$ container was filled with 
an unfixed sample for chlorophyll-a determination.

\section{Results}

\subsection{Physical and Chemical Parameters}

The results of some physical and chemical variables are summarized in Figure 2 and 3. The water temperature values range from $28^{\circ} \mathrm{C}$ to $32.2^{\circ} \mathrm{C}$ throughout the study period. The lowest transparency value $(28 \mathrm{~cm})$ was recorded in May while the highest $(48.5 \mathrm{~cm})$ was recorded in the month of January.
The $\mathrm{pH}$ value of the study area remains $\leq 8.16$ throughout the study interval. Conductivity value peaked $99.0 \mu \mathrm{s} / \mathrm{cm}$ in February and lowest value as $78.0 \mu \mathrm{s} / \mathrm{cm}$ in May. Chemical Oxygen Demand and Biochemical Oxygen Demand values range $(38-40 \mathrm{mg} / \mathrm{L}$ and $13-16 \mathrm{mg} / \mathrm{L})$ respectively. The Total Suspended Solids was high in the month of May $(68 \mathrm{mg} / \mathrm{L})$ and was low in the month of February $(37 \mathrm{mg} / \mathrm{L})$. The micronutrients varied throughout the study period with $\mathrm{N}$ $\mathrm{NO}_{3} \leq 33.0 \mathrm{mg} / \mathrm{L}, \mathrm{P}-\mathrm{PO}_{4} \leq 10.1 \mathrm{mg} / \mathrm{L}, \mathrm{SiO}_{3} \leq 0.004 \mathrm{mg} / \mathrm{L}$ and $\mathrm{SO}_{4} \leq 8.0 \mathrm{mg} / \mathrm{L}$.

Table 1. Variations in some physical and chemical parameters of Yewa Lagoon (December, 2012-May 2013).

\begin{tabular}{|c|c|c|c|c|c|c|}
\hline & MON & & & & & \\
\hline PARAMETERS & DEC. & JAN. & FEB. & MAR. & APR. & MAY \\
\hline Surface water temperature $\left({ }^{\circ} \mathrm{C}\right)$ & 30.2 & 30.8 & 32.2 & 31.8 & 31.3 & 30.5 \\
\hline Transparency $(\mathrm{cm})$ & 37.5 & 48.5 & 35.0 & 34.0 & 30.3 & 28.0 \\
\hline Total Suspended Solids (mg/L) & 49.0 & 46.0 & 37.0 & 45.0 & 56.0 & 68.0 \\
\hline Rainfall (mm) & 13.2 & 0.0 & 28.0 & 50.1 & 165.3 & 340.8 \\
\hline Conductivity $(\mu \mathrm{s} / \mathrm{cm})$ & 94.0 & 97.0 & 99.0 & 83.0 & 80.0 & 78.0 \\
\hline $\mathrm{pH}$ & 8.0 & 7.6 & 8.2 & 7.5 & 7.3 & 7.0 \\
\hline Dissolved Oxygen (mg/L) & 4.5 & 7.6 & 7.1 & 5.1 & 3.6 & 2.8 \\
\hline Biochemical Oxygen Demand (mg/L) & 9.0 & 10.0 & 10.0 & 13.0 & 16.0 & 16.0 \\
\hline Reactive Phosphate (mg/L) & 0.5 & 0.8 & 0.5 & 6.8 & 6.9 & 10.1 \\
\hline Reactive Nitrate (mg/L) & 0.1 & 0.2 & 3.1 & 16.8 & 18.1 & 33.0 \\
\hline Sulphate $(\mathrm{mg} / \mathrm{L})$ & 0.01 & 0.02 & ND & 7.0 & 8.0 & 7.9 \\
\hline Silicate $(\mathrm{mg} / \mathrm{L})$ & 0.003 & 0.004 & ND & 0.003 & 0.002 & 0.003 \\
\hline Chlorophyll a & 0.001 & 0.004 & 0.001 & 0.001 & 0.003 & 0.003 \\
\hline
\end{tabular}

$\mathrm{ND}=$ Not Detected.

\subsection{Biological Characteristics}

The abundance of epiphytic algae on submerged surface of water hyacinth is presented in table 2. Twenty six genera of diatoms, six genera of green algae, four genera of blue green algae and three genera of euglenoids were identified. Among the attached algae, unicellular pinnate forms dominated the sample.

Table 2. Species Abundance of Epiphyton Species that occurred from February to May, 2013 at the Iragbo part of Yewa Lagoon.

\begin{tabular}{|c|c|c|c|c|c|c|}
\hline EPIPHYTON TAXA & DEC. & JAN. & FEB. & MAR. & APR. & MAY \\
\hline \multicolumn{7}{|l|}{ Division: BACILLARIOPHYTA } \\
\hline \multicolumn{7}{|l|}{ Class: BACILLARIOPHYCEAE } \\
\hline \multicolumn{7}{|l|}{ Order: CENTRALES } \\
\hline \multicolumn{7}{|l|}{ Family: COSCINODISCACAEA } \\
\hline Aulacoseira granulata var. augustissima & 195 & 200 & 190 & 175 & 80 & 95 \\
\hline Aulacoseira granulata var. muzzanensis & 200 & 190 & 185 & 140 & 110 & 80 \\
\hline Aulacoseira italica var. subarctica & 110 & 95 & 85 & 70 & 45 & 50 \\
\hline Aulacoseira granulata Ehrenberg & 45 & 35 & 40 & 25 & 20 & 20 \\
\hline Coscinodiscus granii & 10 & - & 5 & - & - & 5 \\
\hline Coscinodiscus nitidus & 20 & 10 & 15 & 10 & - & 5 \\
\hline Cyclotella comta Kutzing & 25 & 20 & 15 & 10 & 5 & - \\
\hline \multicolumn{7}{|l|}{ Order: PENNALES } \\
\hline \multicolumn{7}{|l|}{ Family: FRAGILARIACAEA } \\
\hline Diatoma elongatum & 10 & 15 & - & - & 10 & 15 \\
\hline Fragilaria virescens & - & - & 10 & 15 & - & - \\
\hline Gyrosigma scalproides & 5 & 10 & 5 & 5 & - & - \\
\hline Pediastrum chlathratum & 15 & 10 & 10 & - & 10 & - \\
\hline Pediastrum duplex var. subgranulatum & 25 & 15 & 20 & 10 & - & - \\
\hline Surivella ovate & - & 10 & 15 & - & 5 & - \\
\hline Surirella robusta & 10 & - & 10 & 5 & - & 10 \\
\hline Surirella robusta var. armata & 20 & 15 & - & 15 & - & 10 \\
\hline Surirella robusta var. splendid & 15 & 10 & 15 & 20 & 15 & - \\
\hline Synedra acus & 25 & 20 & - & 25 & 5 & 20 \\
\hline Leptocylindrus daniscus & 50 & 40 & 45 & 20 & - & 10 \\
\hline
\end{tabular}




\begin{tabular}{|c|c|c|c|c|c|c|}
\hline EPIPHYTON TAXA & DEC. & JAN. & FEB. & MAR. & APR. & MAY \\
\hline Leptocylindrus sp. & 25 & 25 & 30 & 15 & 20 & - \\
\hline Dentonula schroderi & 25 & - & 20 & - & 15 & - \\
\hline Stephanodiscus astraea Grunow & 20 & 25 & 25 & 10 & - & 5 \\
\hline Stephanodiscus minutulus & - & 25 & 20 & 5 & - & 10 \\
\hline Tabellaria fenestrata var.intermediata & 10 & 20 & - & 20 & 15 & 20 \\
\hline Melosira islandica & 45 & 50 & 40 & 40 & 30 & 25 \\
\hline Pinnularia major & 20 & 15 & - & 25 & - & 15 \\
\hline Gomphonema parvulum & 15 & 10 & 10 & - & 10 & 5 \\
\hline \multicolumn{7}{|l|}{ Division: CHLOROPHYTA } \\
\hline \multicolumn{7}{|l|}{ Class: CHLOROPHYCEAE } \\
\hline \multicolumn{7}{|l|}{ Order: TETRASPORALES } \\
\hline \multicolumn{7}{|l|}{ Family: TETRASPORACAEA } \\
\hline Asterococcus superbus & 20 & 20 & 25 & - & - & 10 \\
\hline \multicolumn{7}{|l|}{ Order: DESMIDIALES } \\
\hline \multicolumn{7}{|l|}{ Family: DESMIDIACAEA } \\
\hline Desmidium sp. & 5 & - & 5 & 5 & - & - \\
\hline Desmidium swartzii & - & 10 & - & 5 & 10 & 5 \\
\hline Hyalotheca dissiliens & 15 & - & 5 & - & 15 & 5 \\
\hline \multicolumn{7}{|l|}{ Order: VOLVOCALES } \\
\hline \multicolumn{7}{|l|}{ Family: VOLVOCACAEA } \\
\hline Pandorina morum & 5 & 5 & - & 5 & 5 & - \\
\hline Volvox globator & 10 & 5 & 5 & - & - & 5 \\
\hline \multicolumn{7}{|l|}{ Division: CYANOPHYTA } \\
\hline \multicolumn{7}{|l|}{ Class: CYANOPHYCEAE } \\
\hline \multicolumn{7}{|l|}{ Order: NOSTOCALES } \\
\hline \multicolumn{7}{|l|}{ Family: NOSTOCACAEA } \\
\hline Anabaena affinis & 30 & 25 & 30 & 20 & 5 & 10 \\
\hline Anabaena spiroides var.tumida & 10 & 20 & 25 & 30 & 15 & 5 \\
\hline Calothrix pariatina & - & 10 & - & 5 & - & - \\
\hline Tetraëdron regulare var.incus & 10 & - & - & 5 & - & - \\
\hline \multicolumn{7}{|l|}{ Division: EUPHYTA } \\
\hline \multicolumn{7}{|l|}{ Class: EUPHYCEAE } \\
\hline \multicolumn{7}{|l|}{ Order: EUGLENALES } \\
\hline \multicolumn{7}{|l|}{ Family: EUGLENACAEA } \\
\hline Euglena ehrenberghii & 15 & 10 & 15 & - & 10 & 5 \\
\hline Phacus longicauda & 15 & 20 & - & 10 & - & 15 \\
\hline Trachelomonas hispida & 5 & - & - & 5 & 10 & 15 \\
\hline Total species diversity (S) & 34 & 31 & 28 & 29 & 22 & 26 \\
\hline Total abundance $(\mathrm{N})$ & 1080 & 1020 & 920 & 750 & 465 & 475 \\
\hline
\end{tabular}

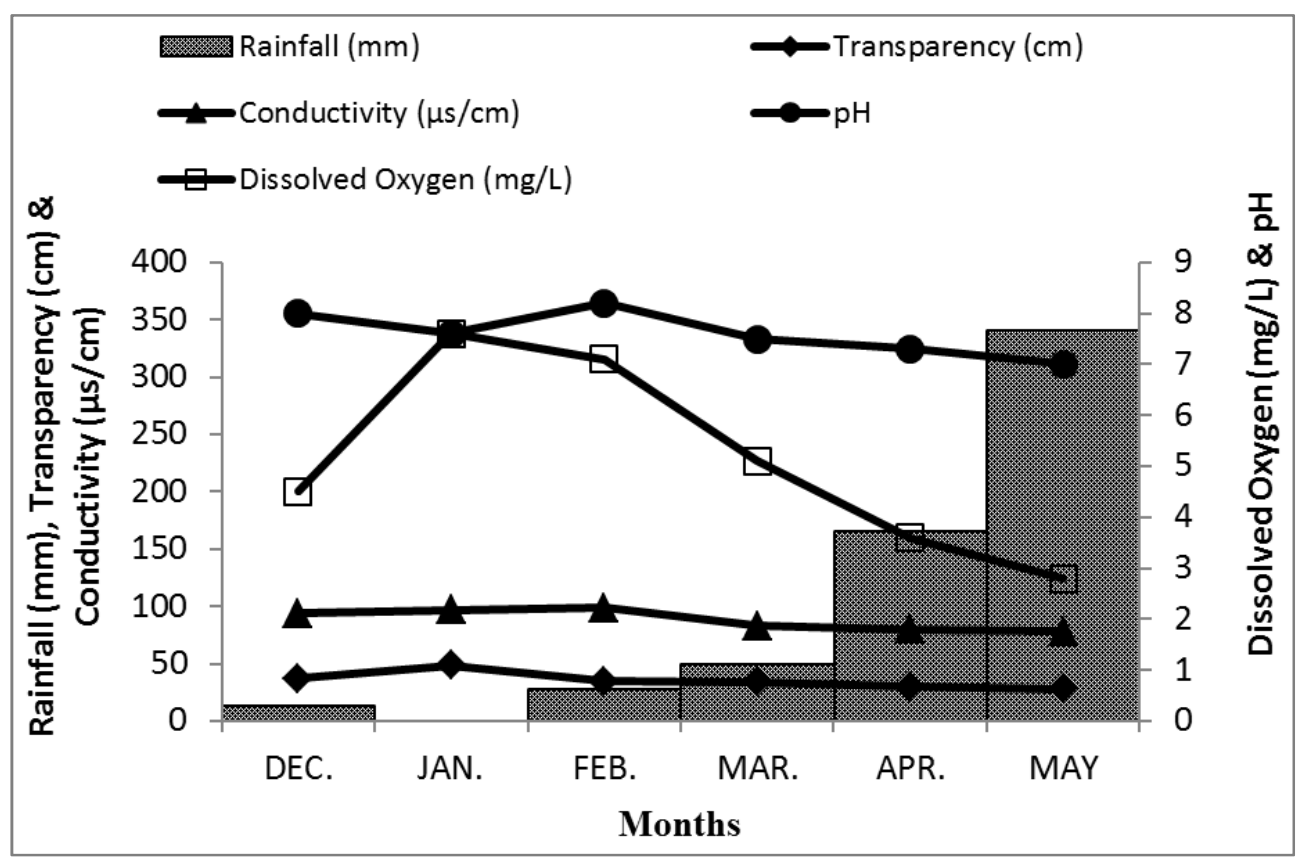

Fig. 2. Monthly variation in Rainfall, Dissolved Oxygen, pH, Transparency and Conductivity in Yewa Lagoon (December, 2012- May, 2013). 


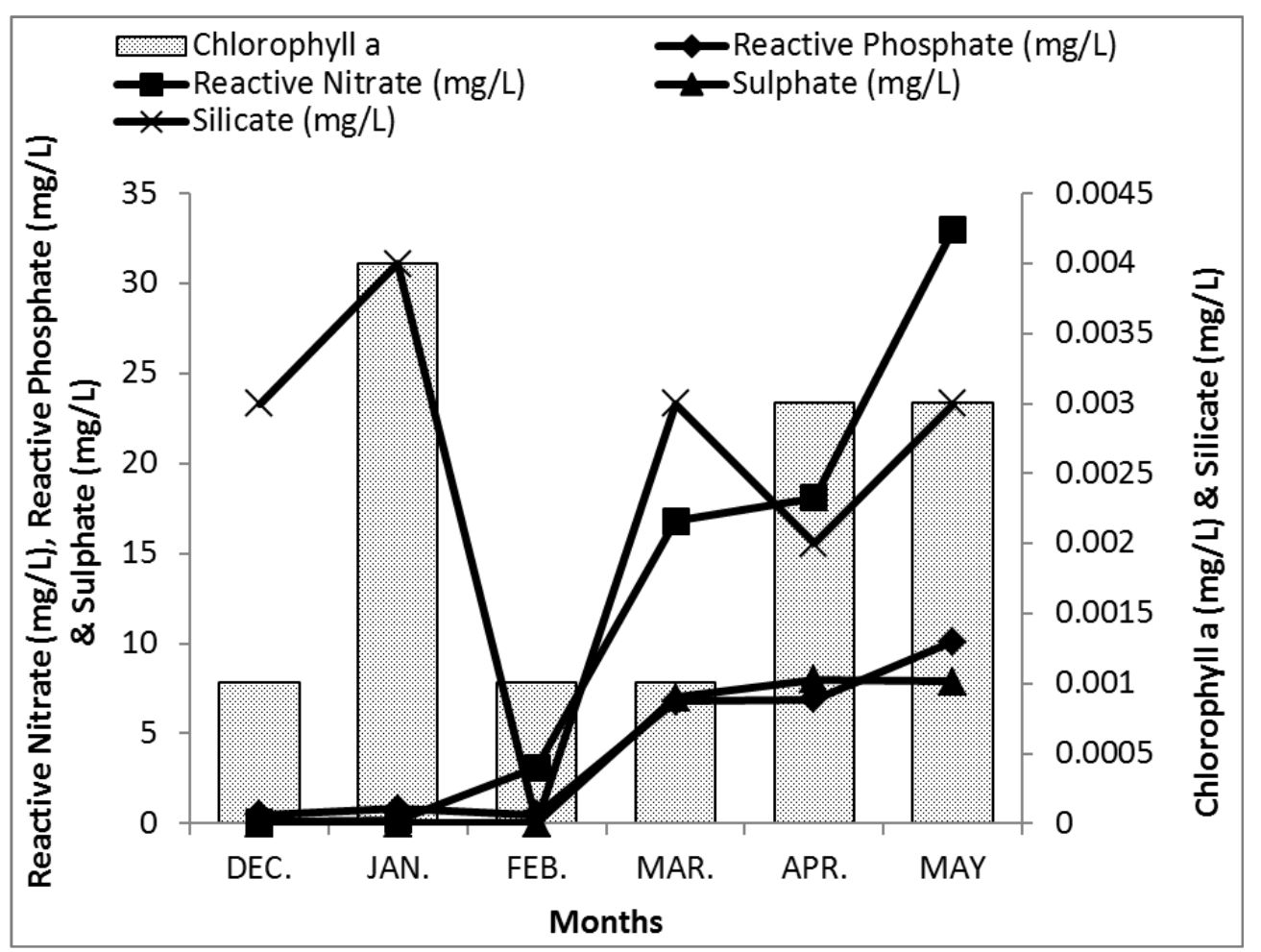

Fig. 3. Monthly variation in Chlorophyll-a, Sulphate, Silicate, Nitrate and Phosphate in Yewa Lagoon (December, 2012- May, 2013).

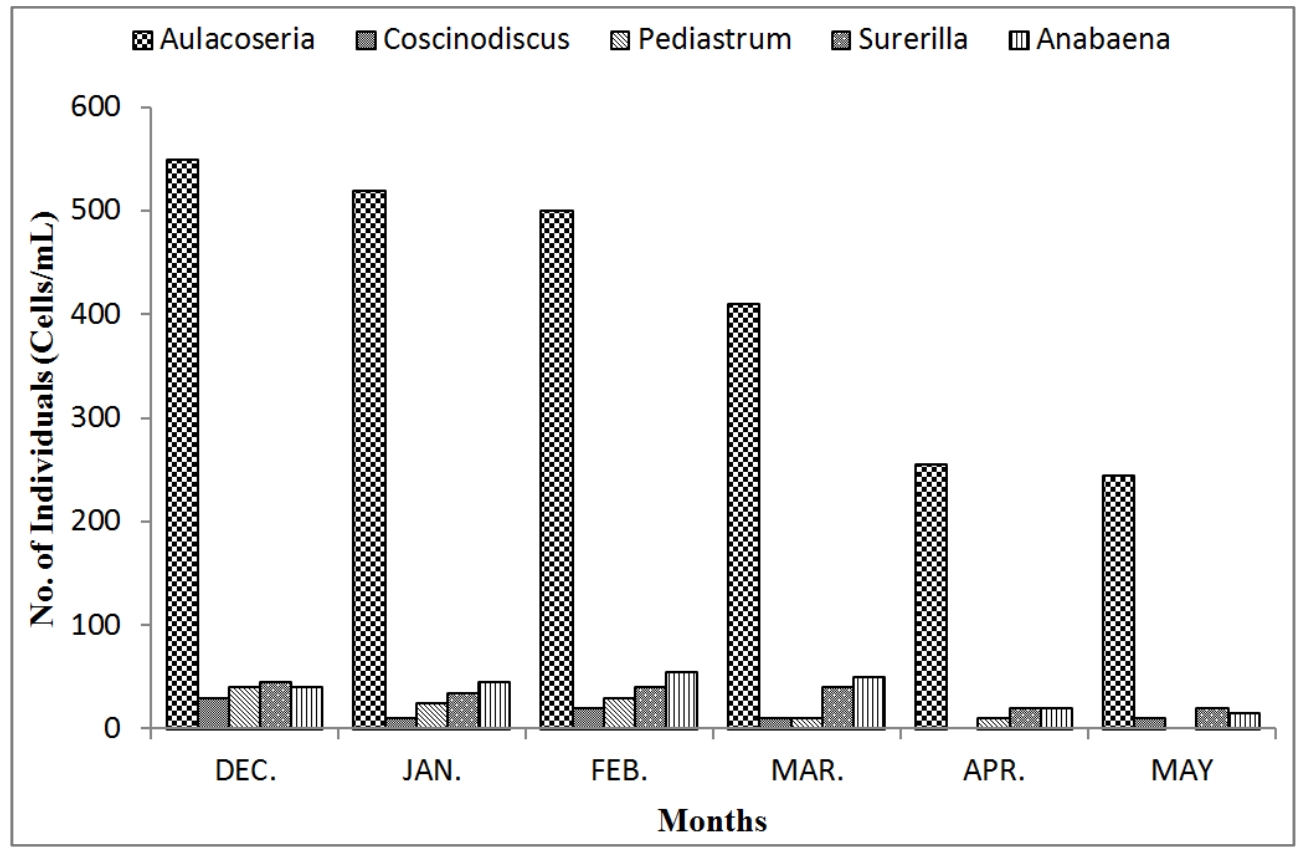

Fig. 4. Variation in the main algal groups in Yewa Lagoon (December, 2012- May, 2013).

\section{Discussion}

The changes in hydroclamatic factors observed in the lagoon may have been as a result of changes in regional whether pattern that linked to the global warming scenarios. As observed during the study the dry months concentrated between December and April. This was accompanied by higher conductivity, higher temperature, higher transparency and higher $\mathrm{pH}$. The high values of $\mathrm{pH}$ observed could be as a result of high bacterial activity in the river. High bacterial activity reduces oxygen level of water rather increases the $\mathrm{CO}_{2}$ level that increase the $\mathrm{pH}$ level. Discharge of effluence by Ewekoro cement industry could as well increased the $\mathrm{pH}$ level of the water. Leachates into the lagoon from Yewa River, associated creeks and wetlands during wet months could influence the physiochemical variables noted. Similar observations have been reported by Nwankwo [29, 30], in Lagos Lagoon. 
The major factors in water quality affected by pollutants are the Dissolved Oxygen and $\mathrm{pH}$. In most cases depletion of oxygen is as a result of bacterial degradation of the organic constituents utilizing oxygen [8]. The low DO value observed at the beginning of the wet months could probably be due to this bacterial degradation of the organic constituents utilizing oxygen introduced into the water. The subsequent increase in DO values in the later parts of the wet months could be due to the rule played by aquatic vegetation in increasing the oxygen levels in the water. Similar observation was made by Barcley [31], in a temporary pond near Auckland, New Zealand.

With the resumption of the rains, surface water temperatures, transparency and light penetration decreased whereas water level increased. Conductivity was comparatively stable all through the months possibly due to lack of intrusion of sea water. Lagoons of south-western Nigeria are known to be of two types, some like the Lagos lagoon and Iyagbe Lagoon directly influenced by tidal sea water are said to be physical while others like the Epe, Ologe, Lekki, Yewa, Kuramo and Badagry Lagoons are said to be biologically controlled [32]. The rising values of micro nutrients between January and March maybe due to reduction of water inflow from the creeks and rivers, it may also be as a result of an increase in water temperature and possible increase in bacteria oxidation, as observed by Thomas [33], in a small man-made lake in Ghana.

The abundance of aquatic macrophytes like Ipomea aquatica Fork, Pistia stratiotes and Eichhornia crassipes by the lagoon sides as well as water surface maybe an indication of the eutrophic level of the lagoon. With the nutrient waste which drains into the lagoon, it could be expected that the algae present would be pollution-tolerant hence could be used as indicator species. Nwankwo and Akinsoji [5], working on periphyton algae of Ogbe Creek Lagos made similar observations. The abundance of epiphytic algae population during the dry months maybe due to the relative stability of the lagoon water.

Diatoms dominated the water hyacinth epiphyton community possibly because of their ability to develop rapidly on newly submerged surfaces. This conformed to the report made by Nwankwo and Onitiri [8] on the phytoplankton community on submerged aquatic macrophyte in Epe lagoon. The presence of species like Gomphonema parvulum(diatom), Synedra accus(diatom), Trachelomonas hispida(euglenoid), Phacus longicuda(euglenoid), Surivella ovata (diatom), Pinnularia major(diatom), and Pondorina morum (green algae) could be used as an indicators of organic pollution. AI Inyang et al [34], Butcher [35] and Palmer [20], made similar observations. This maybe a pointer that Yewa Lagoon is gradually being enriched probably due to several tributaries connected to it or some socioeconomic activities that is taking place in the nearby communities, like application of NPK fertilizer or poultry droplet on farmland. Species like Tetraedon regulare Var. incus, Calothrix pariatina and Coscinodiscus granni may be threatened by the increasing levels of organic pollution.

\section{Conclusion}

There is an abundance of epiphytic algae population during dry months due to relative stability of the lagoon water, this is evidence that during wet months the lagoon receives substantial amounts of inland waters through its several tributary. The BOD values recorded for the lagoon during the sampling period lie below the acceptable limits set by World Health Organisation (WHO) for international water quality standard in coastal waters $(15.9-37.5 \mathrm{mg} / \mathrm{L})$ with warning levels from $(18.9-34.5 \mathrm{mg} / \mathrm{L})$. The low BOD values noted signify high organic load in the water and could be link to the presence of some tolerant species like Gomphonema parvulum(diatom), Synedra accus(diatom), Trachelomonas hispida(euglenoid), Phacus longicuda(euglenoid), Surivella ovata (diatom), Pinnularia major(diatom), and Pondorina morum (green algae).

\section{Acknowledgements}

The authors acknowledge the assistance of the staff of Marine Biology Laboratory, University of Lagos. Special thanks go to Professor D.I. Nwankwo for his expertise contribution in the work.

\section{References}

[1] Egborge, A. B. N (1988). Water hyacinth- Biological museum. Proceedings of International Workshop on Water Hyacinth, Lagos 7-12 August 1988. 52-70.

[2] Nwankwo, D.I. (1984). Seasonal changes of phytoplankton of Lagos and adjacent sea in relation to environmental factors, Ph.D. Thesis. University of Lagos. 447pp.

[3] Nwankwo, D.I. (1988). A preliminary checklist of phytoplankton algae in Lagos Lagoon Nigeria. Nigerian journal of Botanical Applied Sciences. 2 (2): 73-85.

[4] Nwankwo, D.I. (1990). Contribution to the Diatom flora of Nigeria. Diatoms of Lagos Lagoon and the adjacent sea. Nigeria Journal of Botany. 3: 53-70.

[5] Nwankwo, D.I. and Akinsoji, A. (1988). The benthic algal community on water hyacinth Eichhornia crassipes (Mart) Solms. In coastal waters of south western Nigeria, Archivfuer Hydrobiologie. 124 (4): 501-511.

[6] Nwankwo, D.I. (1991). Phytoplankton algae on fish fences 'acadja' in a tropical open lagoon. International Journal of Ecology and Environmental Sciences. 17: 1-10.

[7] Nwankwo, D.I. and Akinsoji, A. (1992). Epiphyte community on water hyacinth Eichhornia crassipes (Mart) Solms. In coastal waters on south-western Nigeria. Archive Hydrobiologie. 124 (4): 501-511.

[8] Nwankwo, D.I. and Onitiri, A.O. (1992). Periphyton community on submerged aquatic macrophytes (Hornwort and Bladderwort) in Epe Lagoon, Nigeria. Agric. Sci. Technol. 2 (2): $135-141$

[9] Gaiser, E. (2008). Epiphyton as an indicator of restoration in the Everglades: Ecological indicators. Elsevier Publishers. 9 (6): $230-248$. 
[10] Lawson, G.W., Peter, I. Biswas, S, Biswas, E.R.I. and Peynolds, J.D. (1969). Hydrobiological work of the volta basin Reasearch Project 1963-1968.Bulletin de L'institut Fundamental d'Afrique Noire, A 36 (1): 51-61.

[11] Lawson, G.W. (1970). Lessons of the Volta- a new man-made lake in the tropical Africa. Biological Conservation. 2: 90-96.

[12] Thomas, J.D., Nwankwo, D.I. and Sterry, P.R. (1985). The feeding strategies of juvenile and adult Biomphalaria glabrata (say) under simulated natural conditions and their relevance to ecological theory and control. Proceedings of the Royal Society, London, B 226: 177-209.

[13] Welch, B.O and Isaac, F.D. (1973). Plant community dynamics in a chain of lakes; principle factors in the decline of rooted macrophytes with eutrophication. Hydrobiologia. 173: $199-415$.

[14] Laugaste, R. and Ruemamen, M. (2005). The composition and density of epiphyton in some macrophyte species in the partly meromictic lake Verevi. Hydrobiologia. Vol. 547.(5).137-150.

[15] Lakatos, G., Kiss, M., Mezaros, I. (1999). Heavy metals contents of common red (phragmite australis/cav./Trini Ex Steudel) and its epiphyton in Hungarian shallow standing waters. Hydrobilogia. Vol. 37(4). S: 437-445.

[16] Michael, E.S. Michael, E.M., Douglas, A.J. (2006). Benthos as the basis for arctic lake food webs. Aquatic Ecology. Vol. 37 (4).430-447.

[17] Lowe, R.L (1996). Periphyton partterns in lakes. In: Stevenson R.J, Bothwell, M.L, Lowe, R.L. (Eds.). Algal Ecology. Freshwater Benthic Ecosystems. 57-76.

[18] Dakashini, K.M.M. and Soni, J.K. (1982). Diatom distribution and status of organic pollution in sewage drains. Hydrobiologia. 87: 205-209.

[19] Munawar, M. (1972). Ecological study of Euglenacaea in certain polluted and unpolluted environments. Hydrobiologia, 39 (3): 307-320.

[20] Palmer, C.M. (1969). A composite rating of algae tolerating organic pollution. Journal of Phacology.2 (1): 79-82.

[21] Valandinghan, L.B. (1976). Peculiarities of epiphyton algal communities formation on different macrophyte species [Skirtingu makrofitu rusiu epifitono dumbliu bendriju formavimosi ypatumai]. Bot.Lith., 18 (2): 154-163.

[22] Saad, M.A.H. and Antoine, S.E. (1983). Effect of pollution on phytoplankton in the Asher canal, a highly polluted canal of the Shatt-Al-Arab Estuary at the Basrah, Iraq. Hydrobiologia. 99 (3): 189-196.
[23] Pentalow, F.K.T, Hynes, H.B and Wilson, C.D (1938). The Biology of Polluted Waters. University of waterloo, Ontario, Canada. 336pp.

[24] Casterlin, M.E. and Reynolds, W.W. (1977). Seasonal succession and cultural eutrophication in a north temperate lake. Hydrobiologia. 54: 99-108.

[25] Munawar, M. (1974). Limnological studies on fresh ponds of Hyderabad, India. IV: The Biocenose-periodicity and species composition of unicellular and colonial phytoplankton in polluted and unpolluted environments. Hydrobiologia, 45: 1-32.

[26] Welch,P.S. (1948). Limnological Methods. McGraw-Hill Book Co., New York, 370pp.

[27] APHA (1998). Standard Methods for the Examination Water and Sewage, $16^{\text {th }}$ ed. American Public Health Association incorporated. Washington D.C. 1268pp.

[28] Forester, J. and Schlichting, H. (1965). Phyco-periphyton in an oligotrophic lake. Transactions of Amrican Microscopic Society. 84: 485-502.

[29] Nwankwo, D.I. (1993). Cyanobacteria bloom species in coastal waters South-West Nigeria. Archive Fur Hydrobiologie. 90: 543-55.

[30] Nwankwo, D.I. (1996). Phytoplankton diversity and succession in Lagos Lagoon, Nigeria. Archive Fur Hydrobiologie. 135 (4): 529-542.

[31] Barclay, M.H. (1966). An ecological study of a temporary pond near Auckland, New Zealand. Australian Journal of Marine and Freshwater Reasearch, 17: 239-258.

[32] Onyenekan, J.A. (1987). Benthic macrofuana communities of Lagos Lagoon Nigeria. Nigerian Journal of Sciences. 21 (182): 45-51.

[33] Thomas, J.D (1966). Some preliminary observation on the fauna and flora of a small man-made Lake in the West African Savanna. Bulletin de L'Institut Foundamental D'Afrique Noire: TXXVIII ser A (2): 542-562.

[34] AI Inyang, KS Effiong and MU Dan (2015). A Comparative Study of the Periphyton on Eichhornia crassipes and Phytoplankton Communities: An Overview of Environmental Conditions at Ejirin Part of Epe Lagoon, South Western Nigeria. British Journal of Applied Science \& Technology. 10(5): 1-23pp.

[35] Buthcher, R.W. (1949). The biological detection of pollution. Institute of sewage purification Journal. 2: 92-97. 